\title{
Az elhízás jelenlegi és prognosztizált betegségterhe a magyarországi romák körében II.
}

\author{
Kiss Anna ${ }^{1}$ - Andó Réka dr. ${ }^{2}$ - Fritz Péter dr. ${ }^{3}$. Lakner Zoltán dr. $^{1}$ \\ ${ }^{1}$ Szent István Egyetem, Élelmiszertudományi Kar, Élelmiszeripari Gazdaságtan Tanszék, Budapest \\ ${ }^{2}$ Semmelweis Egyetem, Általános Orvostudományi Kar, Fül-Orr-Gégészeti és Fej-Nyaksebészeti Klinika, Budapest \\ ${ }^{3}$ Miskolci Egyetem, Egészségügyi Kar, Miskolc
}

Bevezetés: Az elhízás, valamint az elhízással összefüggő krónikus, nem fertőző betegségek prevalenciája növekszik a roma populációban. Az elhízás megelőzését és csökkentését célzó beavatkozások fejlesztésére és tesztelésére fordított hatalmas erőforrások ellenére kevés információ áll rendelkezésre az evidencián alapuló intervenciós programok hatékonyságáról.

Célkitüzés: A roma populációban különböző életkori kategóriákban végrehajtott, eltérő intenzitású intervenciós programok hatásainak modellezése a beavatkozások végrehajtása után bekövetkezett tápláltsági állapot változásában. Módszer: A különböző népegészségügyi beavatkozások hatása a roma lakosság egészségi állapotára a Dynamic Modeling for Health Impact Assessment szoftverrel került meghatározásra. A szerzők a kutatás során kétféle modellbeavatkozást hasonlítottak össze: az elhízás prevenciójának egy tényezőjére, a nagy cukor-, só- és zsírtartalmú élelmiszerek reklámozásának korlátozására fókuszáló intervenciós programokat és a komplex beavatkozás elvére épülő, az életmód egészét megváltoztató intervenciós programok tápláltsági állapotra gyakorolt hatását térképezték fel.

Eredmények: A roma férfiak és nők közel 20\%-a szenved elhízásban jelenleg, népegészségügyi beavatkozás nélkül 2070-re a romák egyharmada lesz túlsúlyos és elhízott. Az elhízás egy tényezőjére fókuszáló intervenciós programok még akkor sem adnak érzékelhető eredményt az elhízás társbetegségeinek incidenciáját és prevalenciáját tekintve, ha a szakirodalomban bemutatott, jelenleg leghatékonyabb eljárásokat alkalmazzák. Ezen intervenciós programok hatása a statisztikai kimutathatóságot is alig éri el. A teljes életmódváltást segítő intervenciós programok elsősorban a közép- és időskorú roma népesség esetén adhatnak érzékelhető eredményt. Az elhízásban szenvedő középkorú férfiak aránya $0,42 \%$-kal, a nők aránya $0,35 \%$-kal csökken.

Következtetés: A kutatás eredményei arra hívják fel a figyelmet, hogy a roma lakosság körében a tápláltsági állapot normalizálása és az elhízás kísérő betegségeinek csökkentése komplex, rasszspecifikus beavatkozást igényel.

Orv Hetil. 2020; 161(27): 1137-1145.

Kulcsszavak: elhízás, roma populáció, prevenció, egészségügyi hatásvizsgálat

\section{Current and future burden of obesity in the Hungarian Roma population II}

Introduction: Population-specific obesity in different age groups and in the Roma population as well as the presence of noncommunicable diseases that are linked to obesity necessitate the development of ethnical-specific prevention and intervention programmes.

Aim: Our goal is to model the effects on nutritional status of interventional programmes of different intensities carried out in various age groups of the Roma population.

Method: We defined the effect of different public health interventions on the state of health of the Roma population by use of the Dynamic Modeling for Health Impact Assessment software. Two models of interventions were studied throughout our research: one that focuses on only one aspect of lifestyle changes; and one that includes radical prevention programmes that aim to change lifestyles as a whole and have an impact on nutritional status.

Results: Nearly $20 \%$ of Roma men and women are obese, and by 2070 , one third of the Roma population will be overweight or obese without any public health intervention. Not even when the most efficient proceedings of the scientific literature are applied do prevention-intervention programmes of moderate-intensity offer a perceptible result about the incidence and prevalence of diseases linked to obesity. In the case of application of these programs, not more than a ten-person order of magnitude decrease can be achieved. This is not enough to prove a statistical detect- 
ability on the population level. Whereas, complex intervention programmes, based on a comprehensive transformation of lifestyle and food consumption patterns can present perceptible outcome primarily among the middle-aged and the elderly.

Conclusion: The survey results direct attention to the fact that reducing the burden of disease in the Roma population caused by obesity is only to be achieved as a complex, all-councils act that requires resources much greater than what is available now.

Keywords: obesity, Roma population, prevention, health impact assessment

Kiss A, Andó R, Fritz P, Lakner Z. [Current and future burden of obesity in the Hungarian Roma population II]. Orv Hetil. 2020; 161(27): 1137-1145.

(Beérkezett: 2020. január 3.; elfogadva: 2020. március 19.)

\section{Rövidítések}

$\mathrm{BMI}=($ body mass index $)$ testtömegindex $;$ DAPPS $=($ Demographic Analysis and Population Projection System) Demográfiai Elemző- és Népesség-előrejelző Rendszer; DYNAMO-HIA $=($ Dynamic Modeling for Health Impact Assessment $)$ Dinamikus Egészségügyi Hatásvizsgálat Modellezés; KSH = Központi Statisztikai Hivatal; TV = televízió

Az elhízás prevalenciája az összes etnikai csoportban nőtt az elmúlt három évtizedben. Egyes nemzeti felmérések arra utalnak, hogy az elhízás tartósan a jelenlegi legmagasabb szintjén van, bár az elhízás az egyes alpopulációkban (például romák) továbbra is növekszik. A roma népesség körében az elhízással összefüggő krónikus betegségek szintje is megnövekedett, összehasonlítva a nem roma lakossággal. Az elhízás prevalenciája és az azzal összefüggő morbiditás, mortalitás, valamint az elhízáshoz kapcsolódó társbetegségek következményei (például az egészségügyi ellátás igénybevétele és költségei) egyre növekednek, ideértve a szív- és érbetegségeket, a diabetes mellitust, a postmenopausalis emlődaganatot, a prosztata- és vastagbéldaganatot. A roma népesség egészségi állapotára és annak javítási lehetőségeire hazákban már évtizedek óta nagy hangsúlyt fektetnek; a cigányság egészségi állapotát javító intézkedések tervezéséhez részletes helyzetelemzés szükséges. Az elhízás a makro- és mikrogazdaságra egyre növekvő terhet ró, emiatt sürgetővé válik az elhízás megelőzési lehetőségeinek kutatása, továbbá a megelőző programok nyomon követése az egész élettartamra vonatkozóan [1-4]. Az elhízás és társbetegségei, valamint ezek megelőzési lehetőségei mind a nemzetközi, mind a hazai szakmai közvélemény érdeklődésének homlokterében állnak [5-8]. Az elhízás egyre növekvő előfordulása miatt a megelőző és kontrollbeavatkozások kidolgozására, fejlesztésére és tesztelésére nagy erőforrásokat fordítottak, azonban ezen programok célcsoportjai, az alkalmazott módszerek, a nyomon követés időtartama és a mért eredmények nagyban különböznek. Az elhízást sikeresen mérséklő intervenciók a fizikai aktivitás növelésén, a táplálkozási szokások megváltoztatásán vagy a mérsékelt energia- megszorításon alapulnak populációs szinten [9]. Az alternatív bizonyítékokon alapuló beavatkozások hatékonyságát a krónikus betegségek megelőzésében rendkívül nehéz összehasonlítani; az Egészségügyi Világszervezet összesen 310 intervenciós programot gyűjtött össze, ezek közül azonban mindössze 51 olyan volt, mely legalább mérsékelten eredményesnek tekinthető. Ezen intervenciós programok ugyanakkor a teljes populációt célozzák meg, és nem rasszspecifikusak [10].

\section{Célkitüzés}

Jelen tanulmányunk célja annak meghatározása, hogy a különböző életkori kategóriákban megvalósuló, egymástól eltérő intenzitású intervenciós programok milyen mértékben hozhatnak változást a roma lakosság tápláltsági állapotában és az elhízás okozta társbetegségek előfordulásában.

Kutatásaink során három hipotézist állítottunk fel:

$\mathrm{H}_{1}$ A jelenlegi kutatások alapján 'best practice'-nek (legjobb gyakorlatnak) tekinthető intervenciók alkalmazásával (a nagy cukor-, só- és zsírtartalmú élelmiszerek reklámozásának korlátozása a TV-ben, rádióban és újságokban) egy-egy korcsoportban megvalósított intervenciós programok révén érzékelhető javulás érhető el az elhízás társbetegségeinek incidenciáját és prevalenciáját tekintve.

$\mathrm{H}_{2}$ A jelenleg alkalmazott programoknál lényegesen nagyobb hatású, a komplex beavatkozás elvére épülő intervenció érdemben járulhat hozzá a romák tápláltsági állapotának változásához.

$\mathrm{H}_{3}$ Az idősebb korcsoportra összpontosító intervenciós programok révén jelentősebb hatás érhető el a tápláltsági állapot változásában, mint ha elsősorban a fiatalabb korcsoportokra fókuszálunk.

\section{Módszer}

A fejlett országok egészségügyi politikájának egyik kiindulópontja, hogy a különböző népegészségügyi intézkedéseknek tudományos bizonyítékokon alapuló (evidence- 
based) modellek és előrejelzések alkossák az alapját. Az egészégügyi hatásvizsgálatok révén megítélhető a különböző (már meglévő vagy tervezés alatt álló) programok, projektek vagy egészségpolitikai intézkedések hatása a vizsgált népesség egészére, illetve annak különböző csoportjaira [11]. Munkánk során a Dynamic Modeling for Health Impact Assessment (DYNAMO-HIA) szoftvert alkalmaztuk, amelynek segítségével mérhető a különböző népegészségügyi beavatkozások hatása a lakosság egészségi állapotára. A vizsgálat kialakításához háromféle információra van szükség: (1) a vizsgált populáció jelenlegi és prognosztizált létszáma; (2) a kockázatoknak kitett csoportok populáción belüli eloszlása; (3) és a különböző kockázati állapotok közötti átmeneti valószínűségek ismerete a populáció egyes korcsoportjai között. A szoftver múködésének alapelve, hogy egy adott időszakban (a modell idő - léptéke az év, ezért adott évben) a különböző kockázati csoportokba tartozó lakosság számának ismerete a bemutatott három információval kiegészítve elégséges a következő évben a különböző kockázati csoportokba sorolt lakosság számának előrejelzésére. Azaz a vizsgált populáció $t$ időpontban jellemző állapota csakis az eggyel korábbi $(t-1)$ időpontban meglévő állapotától és az egyes állapotok közötti átmeneti valószínúségektől függ, így az idősornak nincs emlékezete. Matematikai értelemben ez egy Markov-láncnak felel meg [12]. A modell központi eleme egy olyan adatbázis, amely a különböző kockázati tényezők, jelen esetben az elhízás és az elhízásból adódó társbetegségek közötti sztochasztikus kapcsolatokat tartalmazza. Az egyes átmeneti valószínúségek alapján végzett mikroszimulációk és a demográfiai adatok együttese alapján a szoftveralgoritmus időbeli kiterjesztést készít a vizsgált populáció egyes kockázati csoportjainak számára vonatkozóan. Ezek, valamint az egyes kockázati csoportokhoz tartozó betegségincidencia és -prevalencia értékei alapján lehetőség nyílik a különböző kockázatok okozta betegségterhek korcsoport és nemek szerinti időbeli előrevetítésére, illetve az egyes kockázati tényezők prevalenciáját csökkentő beavatkozások hatásának modellezésére $[13,14]$.

\section{A modell bemeneti paraméterei}

A modell bemeneti adatait három forrásból állítottuk össze:

(1) A Központi Statisztikai Hivatal (KSH) népességstatisztikai adatai alapján megbecsültük a magyarországi roma lakosság demográfiai jellemzőit. Ennek alapján prognózist készítettünk a magyarországi roma lakosság várható létszámára vonatkozóan a Demographic Analysis and Population Projection System (DAPPS) szoftver segítségével.

(2) A roma lakosság tápláltsági állapotát primer mérések alapján határoztuk meg, melyek eredményeit korábbi közleményünkben ismertettük [15].
1. táblázat $\mid$ Az egyes tápláltsági állapotok közötti átmeneti valószínúség százalékos értékei az alapverzió átmeneti valószínűségeihez képest

Az egyes tápláltsági állapotok közötti átmeneti valószínúség

Óvodáskor ( 5 éves)

\begin{tabular}{|c|c|c|}
\hline & Férfi (\%) & Nő (\%) \\
\hline Túlsúlyos-normál & 20 & 20 \\
\hline Elhízott-normál & 10 & 10 \\
\hline \multirow[t]{3}{*}{ Elhízott-túlsúlyos } & 20 & 20 \\
\hline & \multicolumn{2}{|c|}{ Prepubertás (11 éves) } \\
\hline & Férfi (\%) & Nő $(\%)$ \\
\hline Túlsúlyos-normál & 20 & 20 \\
\hline Elhízott-normál & 10 & 10 \\
\hline \multirow[t]{3}{*}{ Elhízott-túlsúlyos } & 20 & 20 \\
\hline & \multicolumn{2}{|c|}{ Középkorú (42 éves) } \\
\hline & Férfi (\%) & Nö (\%) \\
\hline Túlsúlyos-normál & 5 & 5 \\
\hline Elhízott-normál & 3 & 3 \\
\hline \multirow[t]{3}{*}{ Elhízott-túlsúlyos } & 7 & 7 \\
\hline & \multicolumn{2}{|c|}{ Időskor (63 éves) } \\
\hline & Férfi (\%) & Nö (\%) \\
\hline Túlsúlyos-normál & 6 & 6 \\
\hline Elhízott-normál & 3 & 3 \\
\hline Elhízott-túlsúlyos & 7 & 7 \\
\hline
\end{tabular}

(3) Az egyes tápláltsági állapotok közötti átmeneti valószínúségeket (például mennyi a valószínúsége annak, hogy egy 65 éves elhízott férfi 66 éves korára a 'túlsúlyos' kategóriába kerül) a DYNAMO-HIA szoftverben található, a hazai adatokat leginkább megközelítő angol adatbázisból vettük át (1. táblázat). Vizsgálataink időhorizontja 2020-tól 2070-ig, azaz ötven érve terjedt ki. Ez az időszak elégséges ahhoz, hogy az egyes beavatkozások hatásai elemezhetők legyenek.

A modell kiinduló adata a KSH 2011. évi népszámlálása során meghatározott cigányságlétszám volt, azaz 310 ezer fö [16]. Ez a szám eróteljesen alábecsült [17], de arra megfelelő, hogy a tendenciákat konzervatív módon becsülhessük vele. A modell a teljes roma populációt modellezte; a populáció összetételét életkori csoportok és nemek szerinti bontásban a KSH adatai alapján a 2 . táblázat mutatja be.

\section{Modell-intervenciók}

A kutatás során kétféle modell-intervenciót hasonlítottunk össze: az egyiken az egy-egy korcsoportra és az elhízás prevenciójának egy tényezőjére fókuszáló beavatkozások közül az élelmiszerreklámok korlátozásának hatásait elemeztük. A nagy zsír-, cukor- és sótartalmú élelmiszerek reklámjai befolyásolják az étkezési preferenciákat és az élelmiszer-fogyasztást. Az alacsonyabb társa- 
2. táblázat A magyarországi roma populáció összetétele nemek és korcsoportok szerinti bontásban a Központi Statisztikai Hivatal adatai alapján

\begin{tabular}{ccc}
\hline Életkori csoport & Férfi $(\%)$ & Nő $(\%)$ \\
\hline-9 & 11 & 10 \\
$10-19$ & 11,5 & 10,5 \\
$20-29$ & 7,5 & 8,2 \\
$30-39$ & 7 & 7,2 \\
$40-49$ & 5,5 & 5,3 \\
$50-59$ & 5,4 & 3,7 \\
$60-69$ & 3,7 & 2,3 \\
$70-79$ & 0,2 & 0,7 \\
$80-$ & 0,1 & 0,2 \\
\hline
\end{tabular}

dalmi-gazdasági helyzetben lévők nagyobb mértékben vannak kitéve a televíziós (TV-) reklámoknak, mert több időt töltenek TV-nézéssel [18]. A TV mellett az újságokban és a rádióban megjelenő élelmiszerreklámok száma is jelentős. A modell-intervencióban ezért az élelmiszerreklámok korlátozása a rádióban, az újságokban és a TV-ben a nagy zsír-, cukor- és sótartalmú élelmiszerekre vonatkozik.

A másik modell-intervencióban a teljes életmódváltást célzó programok (a fizikai aktivitás növelése, a táplálkozási szokások megváltoztatása, viselkedésterápia) hatásait vizsgáltuk a különböző korcsoportokban. A jelenlegi megelőzési stratégiák elsősorban a viselkedésváltoztatást célzó beavatkozásokra összpontosítanak, míg az elhízás megelőzésében a közösségi/környezeti alapú beavatkozások hiányoznak. A teljes életmódváltást célzó modellintervenció naponta 60-90 perc, közepes intenzitású fizikai aktivitást, az egészséges és kiegyensúlyozott táplálkozást támogató programokat (például OKOSTÁNYÉR ${ }^{\circledR}$ mint a legújabb hazai táplálkozási ajánlás bemutatása mind a gyermekek, mind a felnőttek részére), illetve egészséges táplálkozási és egészségmagatartás kialakulását segítő, egészséges életmódra nevelő programokat (például a táplálkozási tudatosság kialakítása) foglal magában.

A modell-intervenciókhoz azokat az életkori kategóriákat választottuk (óvodáskor: 5 éves, prepubertás: 11 éves, középkorú: 40 év felett, idősödő: 60 év felett), amelyekben a szakirodalmi összefoglalók szerint az intervenciós programok alkalmazása a leghatékonyabbnak bizonyul [19-21].

\section{Statisztikai analizis}

A kutatásban leíró statisztikai módszereket alkalmaztunk a romák tápláltsági állapotának jellemzésére; a tápláltsági állapotban bekövetkező változásokat a Markov-modellen alapuló szimulációs vizsgálatokkal elemeztük. Az eredmények verifikálására nem alkalmaztunk 'bootstrap' eljárást, így nem képződött olyan sztochasztikus alapsokaság, amely alapján további statisztikai vizsgálatokat végezhettünk volna.

\section{Eredmények}

Az eredmények értékelése során figyelembe kell venni, hogy a DYNAMO-HIA az egészségpolitikai tervezést és a népegészségügyi intézkedések döntését támogató szoftver, amely segít számszerüsíteni a népesség egészségi állapotának várható különbségeit, és nem a népesség egészségi állapotának jövőbeli alakulását jelzi előre [22]. A szoftver két vagy több különféle forgatókönyvet (szcenáriót) vesz figyelembe: ezek közül az egyik alapforgatókönyv (beavatkozás nélkül) és egy (vagy több) forgatókönyv, amely(ek)ben intervenció történik. Az eredményeket az egyes forgatókönyvek szerint mutatjuk be.

\section{Alapforgatókönyv, a be nem avatkozás hatása a romák tápláltsági állapotára 2070-re}

Az alapforgatókönyv (beavatkozás nélküli állapot) szerint a magyarországi romák száma 2070-re eléri a 485 ezret. Közel egyharmaduk túlsúlyos és elhízott, a férfiak közül mintegy 30\% túlsúlyos, és 10\%-uk az 'elhízott' kategóriába tartozik. Minden ötödik nő túlsúlyosnak tekinthető, az elhízás aránya körükben 5\%. A férfiak 65\%-a és a nők 78\%-a normál tápláltsági állapotú. Elmondható, hogy a férfiakat nagyobb mértékben fogja érinteni a túlsúly és az elhízás, mint a nőket (3. táblázat).

\section{Az elhizás prevenciójának egy tényezôjére fókuszáló be-} avatkozások hatása

Az elhízás prevenciójának egy tényezőjére fókuszáló intervenciós program - jelen esetben a nagy só-, cukor- és zsírtartalmú élelmiszerek reklámjának korlátozása a TVben, rádióban és az újságokban - esetén feltételezett változásokat az egyes életkori kategóriákban a 4. táblázat foglalja össze. A korcsoportokat tekintve a 4-5. és a 1112. életévben végrehajtott intervenció hatása csekély, az intervenciót követően a normál tápláltsági állapotba kerülők aránya csupán két százalékponttal nőtt mind a fiúk, mind a lányok esetében. A legnagyobb változás a korcsoportokban a 60 év felettiek körében volt kimutatható, az elhízott nők aránya az intervenció után nyolc százalékponttal csökkent. A nemeket tekintve az óvodáskorban

3. táblázat A magyarországi cigányság becsült létszáma és megoszlása tápláltsági állapot szerint 2070-ben az alapverzió (beavatkozás nélküli állapot) szerint

\begin{tabular}{lrrc}
\hline Tápláltsági állapot & Férfi (fö) & Nő (fö) & Összesen (fó) \\
\hline Normál & 151094 & 197912 & 349005 \\
Túlsúlyos & 62202 & 43773 & 105975 \\
Elhízott & 18596 & 11509 & 30105 \\
\hline Összesen & 231892 & 253193 & 485085 \\
\hline
\end{tabular}


Az elhízás prevenciójának egy tényezőjére (nagy cukor-, só- és zsírtartalmú élelmiszerek reklámjának korlátozása a TV-ben, rá dióban és újságokban) összpontosító beavatkozások lehetséges hatásainak modellezése korcsoportok szerinti bontásban

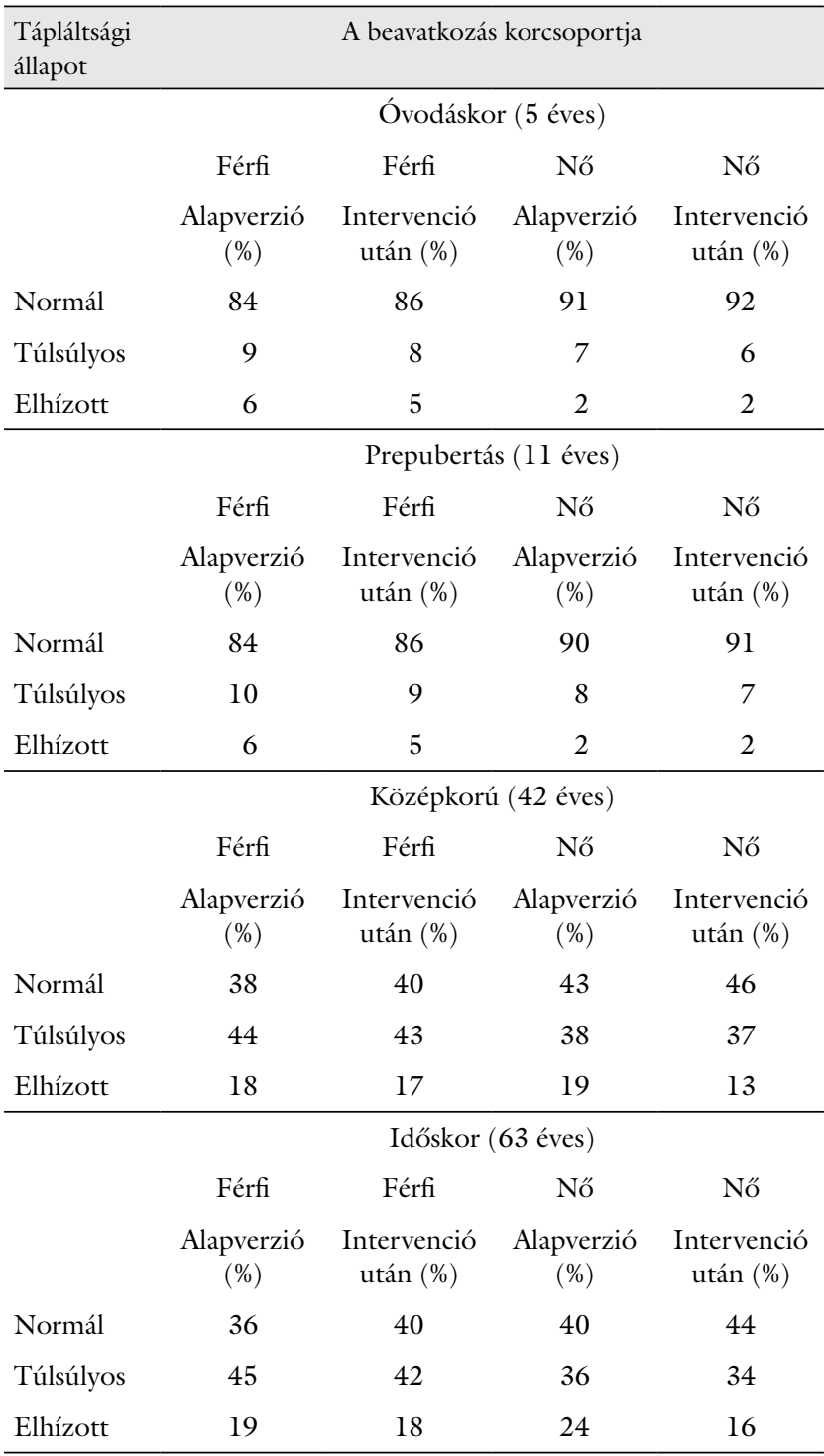

végzett intervenciós programok hatékonysága a férfilakosság körében nem mutatható ki. Az elhízás társbetegségei közül a krónikus obstruktív tüdőbetegség következtében bekövetkezett halálesetek száma várhatóan csökken 30-50 éves távlatban néhány fővel a nők esetében, de a különbség az intervenciós program és az a nélküli állapot között nem éri el az egy ezreléket. Az egyes megbetegedések incidenciája szempontjából ugyancsak nem mutatható ki statisztikai különbség.

Az élelmiszerreklámok korlátozása a TV-ben, rádióban és újságokban mint az elhízás egy prevenciós aspektusára fókuszáló program nem hoz érdemi eredményt a roma lakosság tápláltsági állapotában, mert ez a beavatkozás hosszabb időtávon nem eredményez érzékelhető mértékű javulást az elhízás okozta társbetegségek incidenciájában és prevalenciájában.
5. táblázat $\mid$ A komplex intervenció hatása a tápláltsági állapotra a be nem avatkozáshoz képest 2070-re

\begin{tabular}{|c|c|c|}
\hline Tápláltsági állapot & \multicolumn{2}{|c|}{ A beavatkozás időpontja } \\
\hline & \multicolumn{2}{|c|}{ Óvodáskor (5 éves) } \\
\hline & Férfi $(\%)$ & Nő $(\%)$ \\
\hline Normál & $+0,15$ & $+0,12$ \\
\hline Túlsúlyos & $+0,12$ & $+0,04$ \\
\hline \multirow[t]{3}{*}{ Elhízott } & $-0,10$ & $-0,13$ \\
\hline & \multicolumn{2}{|c|}{ Prepubertás (11 éves) } \\
\hline & Férfi $(\%)$ & Nő (\%) \\
\hline Normál & $+0,32$ & $+0,73$ \\
\hline Túlsúlyos & $+0,07$ & $+0,05$ \\
\hline \multirow[t]{3}{*}{ Elhízott } & $-0,31$ & $-0,37$ \\
\hline & \multicolumn{2}{|c|}{ Középkorú (42 éves) } \\
\hline & Férfi (\%) & Nö (\%) \\
\hline Normál & $+0,41$ & $+0,543$ \\
\hline Túlsúlyos & $-0,31$ & $-0,22$ \\
\hline \multirow[t]{3}{*}{ Elhízott } & $-0,42$ & $-0,35$ \\
\hline & \multicolumn{2}{|c|}{ Időskor (63 éves) } \\
\hline & Férfi (\%) & Nő (\%) \\
\hline Normál & $+0,661$ & $+0,503$ \\
\hline Túlsúlyos & $-0,37$ & $-0,42$ \\
\hline Elhízott & $-0,42$ & $-0,27$ \\
\hline
\end{tabular}

3. A komplex beavatkozás elvére épülo", az életmód egészének megváltoztatását célzó intervenciós programok hatásai

Az életmódváltás egészének átformálása esetén azt feltételeztük, hogy a tápláltsági állapotban sikerül egy-egy életkori csoportban jelentős változást elérnünk. Az egyes korcsoportokban bekövetkező változások százalékos értékeit az 5. táblázat foglalja össze.

\section{A normál tápláltsági állapot alakulása a komplex intervenció hatására}

A különböző életkorokban alkalmazott intervenciós programok eltérő módon hatnak a tápláltsági állapotra. A 1. ábra azt mutatja, hogy a normál tápláltsági állapotú romák száma a komplex intervenció hatására növekedést mutat a be nem avatkozó (baseline) szcenárióhoz képest. $\mathrm{Az}$ óvodáskorban végzett beavatkozás eredményeként növelhető a normál tápláltsági állapotúak összlétszáma 2070-re. A normál tápláltsági állapotba kerülők száma az óvodáskorú fiúk esetében 0,15\%-kal, míg a lányok esetében $0,12 \%$-kal fog nőni. A roma lakosságban hosszabb távon az idősödőkre fókuszáló intervenciós programok lényegesen nagyobb növekedést eredményeznek, a férfiaknál 0,66\%-os, a nóknél 0,5\%-os e növekedés a normál tápláltsági állapot változásában. 


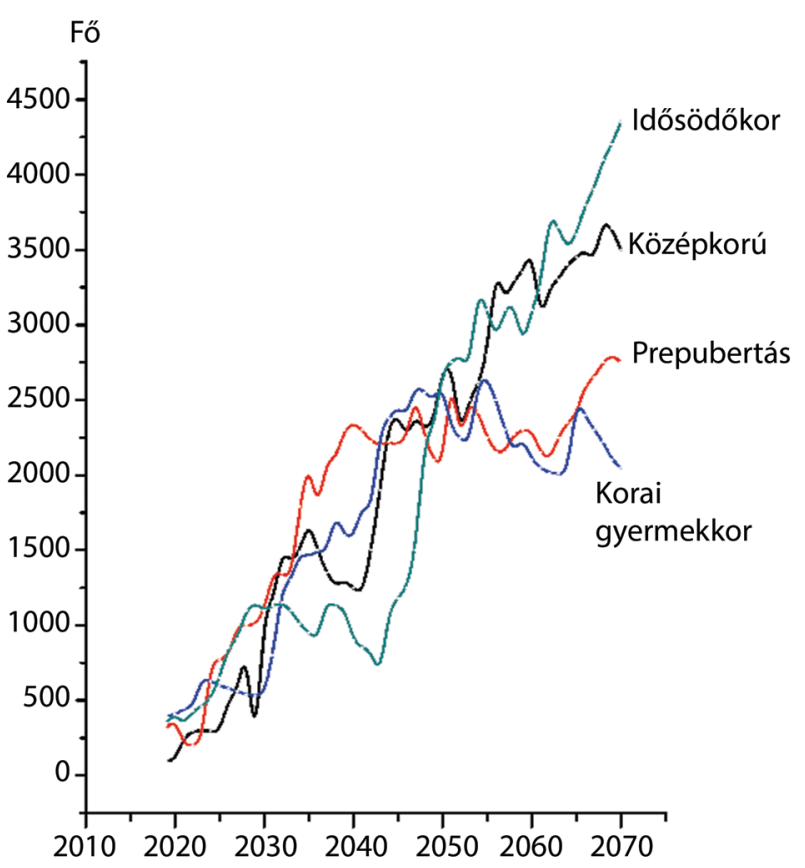

1. ábra

A normál tápláltsági állapot alakulása a komplex intervenció hatására a romák körében az egyes korcsoportokban

\section{A túlsúly és az elhizás alakulása a komplex intervenció hatására}

A túlsúlyosak számának csökkentése szempontjából az óvodáskorban és a prepubertás időszaka alatt alkalmazott intervenciós programok mintegy ezerötszáz-kétezer fővel csökkentik a túlsúlyosak számát a vizsgált időszak második felében. Az intervenció hatására 2070-ben az óvodáskorúak körében a túlsúlyosak száma a fiúknál 0,12\%-kal, a lányoknál pedig 0,04\%-kal változik. Ez a népességszám a középkorú és az idősebb korú népességre fókuszáló beavatkozások esetén csak a XXI. század hatvanas éveiben csökken ötszáz fó alá. A középkorúak esetén a túlsúlyban szenvedők aránya a férfiak körében 0,31\%-kal, a nőknél 0,22\%-kal csökken. A legnagyobb mértékú változás a túlsúlyos romák számát tekintve az időskori beavatkozás hatására történik, a férfiaknál

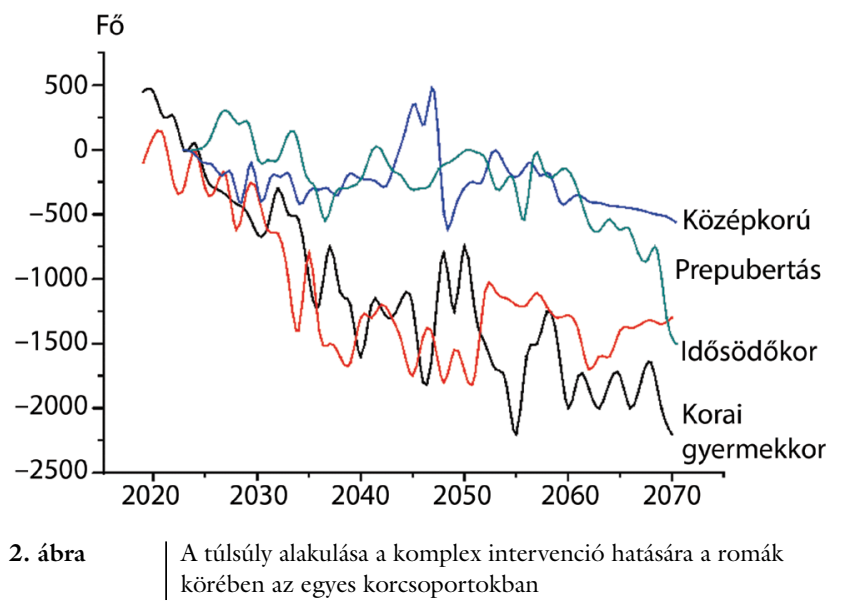

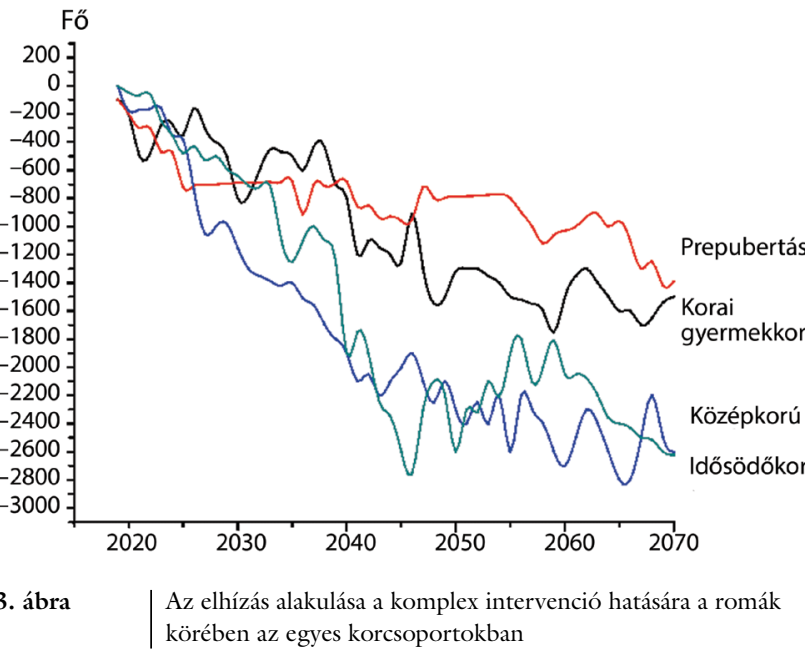

0,37\%-kal, a nőknél 0,42\%-kal csökken a túlsúlyban szenvedők aránya.

Ha az elhízottak számát tekintjük, akkor a középkorúak és az idősödők körében végzett intervenciós programoknak lényegesen nagyobb a hatékonyságuk, mint a korai gyermekkorban vagy a prepubertás időszakában végrehajtott megelőző és korrekciós intézkedéseknek (2. és 3. ábra). A középkorúak között végrehajtott intervenció hatására a férfiak esetén $0,42 \%$-kal, a nőknél 0,35\%-kal csökken az elhízásban szenvedők száma, míg az óvodáskori intervenció eredményeként a fiúknál csupán $0,10 \%$-os, a lányoknál $0,13 \%$-os csökkenés tapasztalható.

\section{Az elhizás társbetegségeinek változása a komplex intervenció hatására}

A bemutatott összefüggések a kockázati csoportok arányáról adnak képet, ez még nem elégséges ahhoz, hogy felmérjük a különböző megbetegedések prevalenciáját. Ha például az ischaemiás szívbetegség prevalenciáját

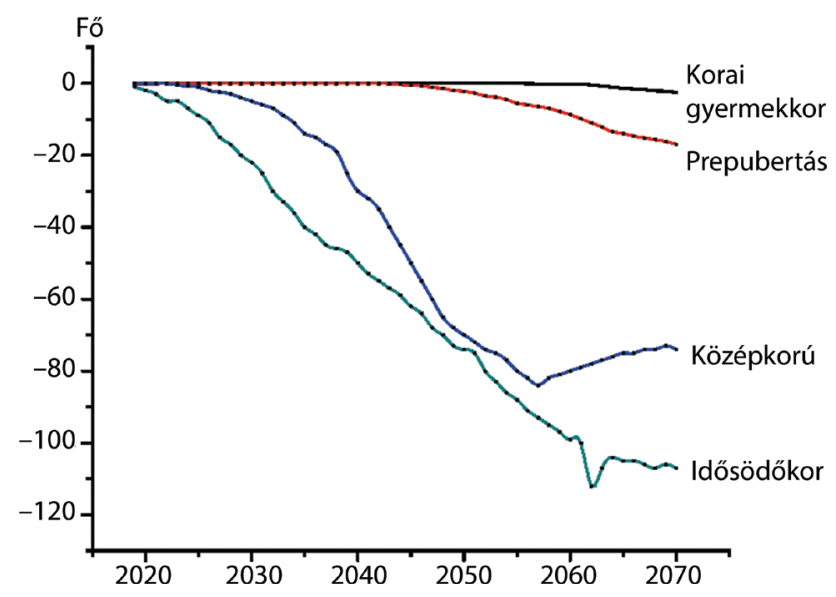

\begin{tabular}{l|l} 
4. ábra & $\begin{array}{l}\text { Az ischaemiás szívbetegség prevalenciájának változása a } \\
\text { komplex intervenció hatására a romák körében az egyes } \\
\text { korcsoportokban }\end{array}$
\end{tabular} 
tekintjük, akkor az figyelhető meg, hogy a korai gyermekkorban végzett beavatkozások szinte semmilyen mértékben nem csökkentik ezen megbetegedések arányát. A prepubertás időszakában végzett prevenciós és intervenciós programok ezzel szemben már érzékelhető javulást hoznak, de ez csak a vizsgált időszak második felében látható. A legjobb eredmények az idősödő népesség körében megvalósított programokkal érhetők el (4. ábra).

\section{Következtetések}

Az elhízás egy tényezőjére fókuszáló intervenciós programok nem hoznak érdemi eredményt a roma lakosság tápláltsági állapotában. A jelenleg 'best practice'-nek tekintett, az elhízás egy tényezőjére fókuszáló intervenciós programok alkalmazásával (például a nagy cukor-, só- és zsírtartalmú élelmiszerek reklámozásának korlátozása a TV-ben, rádióban és újságokban) nem érhető el érzékelhető javulás az elhízás társbetegségeinek incidenciáját és prevalenciáját tekintve. A 4. táblázatban bemutatott értékek eredményei megegyeznek a témával foglalkozó, korszerü szakirodalmi forrásokat elemző tanulmányok alapján fellelhető intervenciós programok eredményeivel, amelyek szerint a legkedvezóbb esetben megközelítőleg két százalékponttal csökkenthető az elhízás mértéke egy-egy korcsoport tápláltsági állapotában az intervenciók hatásának eredményeként [23-25].

A komplex beavatkozás elvére épülő intervenció érdemben járulhat hozzá az elhízás előfordulásának csökkenéséhez. A legnagyobb mértékű változás a középkorúak körében tapasztalható, a férfiaknál 0,42\%-kal, a nőknél pedig 0,35\%-kal csökken az elhízásban szenvedők aránya. A vizsgált populációban ez az eredmény tekinthetó a legkedvezőbb esetnek, amelyben a férfiaknál 7810 fővel, míg a nőknél 4028 fővel csökken az elhízottak száma. Az intervenciók népegészségügyi hatásának értékelésére figyelemre méltó Caballero (2019) példája: Kuba, Latin-Amerika legfejlettebb egészségügyi rendszerével rendelkező országa az 1990-es évek elején mélyreható gazdasági válságot élt át; a lakosság jövedelme és élelmiszer-fogyasztása erőteljesen csökkent, a magas energiaárak miatt egyre kevésbé volt lehetőség a tömegközlekedés és a gépjármúvek használatára. Ennek következtében a lakosság tömegei jártak munkába az állami támogatással vagy ingyen adott kerékpárokon. Elmondható, hogy egy tízmilliós populáció energiabevitel-csökkentésre és fokozott testmozgásra kényszerült, ennek eredményeként azonban átlagosan csupán 1,5 egység $\left(\mathrm{kg} / \mathrm{m}^{2}\right)$ BMI-csökkenés volt kimutatható. Összehasonlításul: az Egyesült Államokban mintegy 5 egység BMI-csökkentést kellene elérni a - kubaival ellentétben - nagy energiasưrűségü élelmiszerek fogyasztása és mozgásszegény életmód mellett [26].

A nemzetközi intervenciós programoknak sok esetben a gyermekek és a tinédzserek alkotják a célcsoportját. Eredményeink azonban azt mutatják, hogy nem igazol- ható az óvodai intervenciós programok hatása az elhízás társbetegségeinek incidenciájára és prevalenciájára, sem az elhízás egy tényezőjére fókuszáló, sem a komplex beavatkozás esetén. A legkedvezóbb eredmények a középés időskorúaknál végzett intervencióval érhetők el, de az incidencia- és prevalenciaértékek itt is alig érik el a statisztikai kimutathatóság határát. Ezen eredményeink összhangban állnak Lhachimi és mtsai (2013) megállapításaival [27].

\section{A komplex beavatkozás lehetôségi és korlátai a romákat megcélzó prevenciós programokban}

A kaliforniai krónikus betegségmegelőzési projekt keretében kidolgoztak egy, a krónikus betegségek megelőzését célzó keretirányelvet, amelynek központi témája az elhízás volt. Fontos szempont, hogy az irányelv olyan egészségügyi célok azonosítására hívta fel a figyelmet, amelyek „elérhetők, mérhetők, és az egészséggel kapcsolatos méltányossági intézkedéseket is magukban foglalnak". Ezen túl lehetőséget kell, hogy nyújtsanak a krónikus betegségek megelőzésére irányuló, szélesebb körú erőfeszítések támogatására. Az elhízás előfordulásának csökkentése meghatározó szerepet játszik a krónikus betegségek megjelenésében lévő egyenlőtlenségek csökkentésében [28]. Az alacsony szocioökonómiai státusz hatszoros rizikó az elhízás kialakulására, ezért a roma lakosság különösen veszélyeztetett. Sándor és mtsai kutatása alátámasztja, hogy a társadalmi-gazdasági helyzet és az etnikai hovatartozás fontos tényezók a prevenciós szolgáltatások igénybevételének meghatározásához. Felmérésük eredményei szerint a romák kisebb arányban veszik igénybe a cardiometabolicus prevenciós lehetőségeket az alapellátásban, ami hozzájárulhat az egészségegyenlőtlenségek növekedéséhez [29]. Hegedüs és mtsai (2014) megállapították, hogy a roma munkanélküliek közegészségügyi-járványügyi biztonsága alacsonyabb szintű az Ózdi kistérségen belül. A roma munkanélküliek túlnyomó többsége hátrányosabb helyzetben van a nem roma munkanélküliekkel összehasonlítva [30].

Európában az alacsony-közepes jövedelmú lakosság egészségének növelésére jött létre a Feel4Diabetes nevű program, amely egy bizonyítékokon alapuló, potenciálisan költséghatékony, iskolai és közösségi alapú intervenció. A program célja az egészséges életmód előmozdítása, valamint az elhízással kapcsolatos metabolicus kockázati tényezők és a 2-es típusú diabetes mellitus megelőzése hat európai országban [31]. A projekt 2019-ben zárult le, eredményei mintaként szolgálhatnak az alacsony-közepes jövedelmú lakosság körében közösségi alapú intervenció tervezéséhez.

A bemutatott eredmények felvetik annak dilemmáját, mekkora az a befektetés, amely már érdemi javulás kialakítására képes a roma lakosság tápláltsági állapotát tekintve. A kérdés megválaszolása azért nehéz, mert a jelenlegi, nemzetközi szakirodalom rendkívül megosztott. A roma lakosság tápláltsági állapotának normáltarto- 
mányba való terelése annyira összetett kérdés, hogy egyegy terület kiragadásával nem oldható meg, az intervencióknak a komplex beavatkozás elvén kell alapulniuk.

Economos és mtsai (2001) szerint az egészségi állapottal kapcsolatos magatartás megváltoztatásához kilenc feltétel együttesére van szükség [32]:

1. a válság felismerése,

2. tudományos, bizonyítékokon alapuló adatok,

3. érzékelt gazdasági előny,

4. karizmatikus vezetők,

5. az érintettek koalíciója,

6. kormányzati támogatás,

7. tömegkommunikációs támogatás,

8. a környezet megváltoztatása,

9. a fenti tényezóket egységbe foglaló, átfogó stratégiai terv.

Fésüs és mtsai (2012) olyan alapelveket dolgoztak ki, amelyek meghatározók a romák egészségi és szociális helyzetének javítását támogató politikai kezdeményezések sikeréhez [33]. Ezen alapelvek alapján olyan komplex cselekvési programra volna szükség a roma népesség tápláltsági állapotának és táplálkozásának optimalizálásához, melynek fóbb elemei a következők:

1. A roma lakosság élelmiszer-fogyasztásának és táplálkozásának részletes megismerése: az elmúlt években részletes felmérések készültek a cigányság egészségi állapotáról, de élelmiszer-fogyasztásukról és az egyes vásárlói döntések hátteréről továbbra sincsenek adatok. A rendszeres adatgyưjtéshez, az adatok feldolgozásához és az eredmények értékeléséhez a modern orvosi antropológia, szociológia és a posztmodern kutatások eszközeinek kiterjedt alkalmazására lenne szükség.

2. A potenciális 'stakeholderek' (bevonható szervezetek) feltárása: a romák egészségi állapotának növelésében fontos szerep juthat az egyházaknak, az iskoláknak, a sportegyesületeknek, az önkormányzatoknak éppúgy, mint a roma közösség önszerveződő egyesületeinek.

3. A cigányság közgazdasági (pénzkezelési) gyakorlatát, egészségmúveltségét és egészségmagatartását javító oktatóprogramok kialakítása, múködtetése és folyamatos monitorozása

4. A fenti három cél együttes elérését lehetővé tevô erőforrások és politikai elköteleződés.

Anyagi támogatás: K. A. németországi, a jelen tanulmányban felhasznált DYNAMO-HIA szoftver megismerését szolgáló féléves tanulmányútját a Német Katolikus Tudományos Csereszolgálat (KAAD), a kutatás megvalósítását az EFOP-3.6.3-VEKOP-16-2017-00005. számú program támogatta.

Szerzői munkamegosztás: A kutatási koncepció, a kutatás módszertani háttere, az adatok értelmezése: K. A., L. Z. Szakirodalmi feldolgozás: K. A., A. R., F. P. Primer adatgyưjtés: K. A., F. P., A. R. Számítógépes futtatások: L. Z.
A cikk első verziójának megírása és a cikk véglegesítése: K. A. A szerzők a cikk végleges változatát elolvasták és jóváhagyták.

Érdekeltségek: A szerzőknek nincsenek érdekeltségeik.

\section{Köszönetnyilvánítás}

A szerzők köszönetüket fejezik ki a Szent István Egyetem Élelmiszertudományi Doktori Iskolájának a kutatás lebonyolításának támogatásáért.

\section{Irodalom}

[1] Avery C, Holliday K, Chakladar S, et al. Disparities in early transitions to obesity in contemporary multi-ethnic US populations. PLoS ONE 2016; 11: e0158025.

[2] Grubbs S, Polite B, Carney J Jr, et al. Eliminating racial disparities in colorectal cancer in the real world: it took a village. J Clin Oncol. 2013, 31: 1928-1930.

[3] Krueger P, Reither E. Mind the gap: race/ethnic and socioeconomic disparities in obesity. Curr Diab Rep. 2015; 15: 95.

[4] Kósa K, Lénárt B, Ádány R. Health status of the roma population in Hungary. [A magyarországi cigány lakosság egészségi állapota.] Orv Hetil. 2002; 143: 2419-2426. [Hungarian]

[5] Wadden TA, Bray GA. (eds.) Handbook of obesity treatment. Guilford Press, New York, NY, 2018.

[6] Ábrahám I, Jambrik M, John B, et al. Body image and body image distortion. [A testképtől a testképzavarig.] Orv Hetil. 2017; 158: 723-730. [Hungarian]

[7] Fekete M, Pongor V, Fehér Á, et al. Relationship of chronic obstructive pulmonary disease and nutritional status - clinical observations. [Krónikus légzőszervi betegek tápláltsági állapotának vizsgálata - klinikai megfigyelések.] Orv Hetil. 2019; 160: 908913. [Hungarian]

[8] Nádasdi Á, Somogyi A, Igaz P, et al. Non-alcoholic fatty liver disease - a summary and update based on the EASL-EASDEASO Clinical Practice Guidelines of 2016. [Nem alkoholos zsírmájbetegség - a 2016. évi közös EASL-EASD-EASO klinikai ajánlás fényében.] Orv Hetil. 2018; 159: 1815-1830. [Hungarian]

[9] Kubendran S. Weighing solutions to obesity. An overview of studies on prevention and intervention. Milken Institute Public Health Summit, Santa Monica, CA, 2016. Available from: https://milkeninstitute.org/sites/default/files/reports-pdf/ Weighing\%20Solutions\%20to\%20Obesity.pdf [accessed: March $18,2020]$.

[10] World Health Organization. Interventions on diet and physical activity: what works. Evidence tables. WHO, Geneva, 2009. Available from: https://apps.who.int/iris/bitstream/handle/ 10665/44139/9789241598255_eng.pdf [accessed: March 18, 2020].

[11] Molnár A, Ádány R, Ádám B, et al. Health impact assessment and evaluation of a Roma housing project in Hungary. Health Place 2010; 16: 1240-1247.

[12] Vizvári B. Operation research models. [Operációkutatási modellek.] Typotex Kiadó, Budapest, 2008. [Hungarian]

[13] Lhachimi SK, Boshuizen HC, Mondeel RL, et al. DYNAMO HIA. A Dynamic Model for Health Impact Assessment. USER GUIDE AND MANUAL. Version 2.0.8. Available from: https://www.dynamo-hia.eu/sites/default/files/2018-04/ DYNAMO_USERMANUAL_2.0.8_0.pdf [accessed: March 18, 2020].

[14] Boshuizen HC. Detailed description of DYNAMO-HIA calculations. 2010. Available from: https://www.dynamo-hia.eu/ 
sites/default/files/2018-04/detailed\%20model\%20specification_cdl_0.pdf [accessed: March 18, 2020].

[15] Kiss A, Andó R, Fritz P, et al. Current and future burden of obesity at the Hungarian Roma population I. [Az elhízás jelenlegi és prognosztizált betegségterhe a magyarországi romák körében I.] Orv Hetil. 2019; 160: 1097-1104. [Hungarian]

[16] Central Statistical Office. Population census - 2011. National data. [Központi Statisztikai Hivatal. Népszámlálás - 2011. Nemzetiségi adatok.] Available from: http://www.ksh.hu/ nepszamlalas/tablak_nemzetiseg [accessed: March 18, 2020]. [Hungarian]

[17] Pénzes J, Tátrai P, Pásztor IZ. Changes in the spatial distribution of the Roma population in Hungary during the last decades. [A roma népesség területi megoszlásának változása Magyarországon az elmúlt évtizedekben.] KSH Területi Statisztika 2018; 58: 3-26. [Hungarian]

[18] Brown V, Ananthapavan J, Veerman L, et al. The potential costeffectiveness and equity impacts of restricting television advertising of unhealthy food and beverages to Australian children. Nutrients 2018; 10: 622.

[19] Weihrauch-Blüher S, Kromeyer-Hauschild K, Graf C, et al. Current guidelines for obesity prevention in childhood and adolescence. Obes Facts 2018; 11: 263-276.

[20] Kjøllesdal MK, Ariansen I, Næss ØE. Early adulthood weight, subsequent midlife weight change and risk of cardiovascular disease mortality: an analysis of Norwegian cardiovascular surveys. Int J Obes. 2020; 44: 399-408.

[21] Zamboni M, Mazzali G. Obesity in the elderly: an emerging health issue. Int J Obes. 2012; 36: 1151-1152.

[22] Lhachimi S, Nusselder WJ, Smit HA, et al. DYNAMO-HIA - a dynamic modeling tool for generic health impact assessments. PLoS ONE 2012; 7: e33317.

[23] Doak CM, Visscher TL, Renders, CM, et al. The prevention of overweight and obesity in children and adolescents: a review of interventions and programmes. Obes Rev. 2006; 7: 111-136.

[24] McKinnon R, Siddiqi S, Chaloupka F, et al. Obesity-related policy/environmental interventions: a systematic review of economic analyses. Am J Prev Med. 2016; 50: 543-549.
[25] Rivera J, McPherson A, Hamilton J, et al. Mobile apps for weight management: a scoping review. JMIR Mhealth Uhealth 2016; 4 : e87.

[26] Caballero B. Humans against Obesity: Who will win? Adv Nutr. 2019; 1 (suppl_l): 4-9.

[27] Lhachimi SK, Nusselder WJ, Lobstein TJ, et al. Modelling obesity outcomes: reducing obesity risk in adulthood may have greater impact than reducing obesity prevalence in childhood. Obes Rev. 2013; 14: 523-531.

[28] California Department of Public Health. California Chronic Disease Prevention Leadership Project. The CCLHO-CHEAC Chronic Disease Prevention Framework. Sacramento, CA, 2013. Available from: https://www.cdph.ca.gov/Programs/CCLHO/ Pages/California-Chronic-Disease-Prevention-LeadershipProject-.aspx [accessed: March 18, 2020].

[29] Sándor J, Nagy A, Földvári A, et al. Delivery of cardio-metabolic preventive services to Hungarian Roma of different socio-economic strata. Fam Pract. 2017; 34: 83-89.

[30] Hegedús I, Morvai V, Rudnai P, et al. Public health issues of the Roma and non-Roma unemployed in the Ózd microregion of Hungary. [Roma és nem roma munkanélküliek közegészségügyi helyzete az Ózdi kistérségben.] Orv Hetil. 2014; 155: 582-589. [Hungarian]

[31] Manios Y, Androutsos O, Lambrinou CP, et al. A school- and community-based intervention to promote healthy lifestyle and prevent type 2 diabetes in vulnerable families across Europe: design and implementation of the Feel4Diabetes-study. Public Health Nutr. 2018; 21: 3281-3290.

[32] Economos CD, Brownson RC, DeAngelis MA, et al. What lessons have been learned from other attempts to guide social change? Nutr Rev. 2001; 59: S40-S65.

[33] Fésüs G, Östlin P, McKee M, et al. Policies to improve the health and well-being of Roma people: the European experience. Health Policy 2012; 105: 25-32.

(Kiss Anna,

Budapest, Villányi út 29-43., 1118 e-mail: anna.kiss@pro-sharp.hu)

\section{"Nec vita nec fortuna hominibus perpes est." (Sem az élet, sem a szerencse nem tart örökké az emberek számára.)}

A cikk a Creative Commons Attribution 4.0 International License (https://creativecommons.org/licenses/by/4.0/) feltételei szerint publikált Open Access közlemény, melynek szellemében a cikk bármilyen médiumban szabadon felhasználható, megosztható és újraközölhetö, feltéve, hogy az eredeti szerző és a közlés helye, illetve a CC License linkje és az esetlegesen végrehajtott módosítások feltüntetésre kerülnek. (SID_1) 